Review

\title{
Antimicrobial Properties of Antidepressants and Antipsychotics-Possibilities and Implications
}

\author{
Marina Caldara ${ }^{1,2, *(1)}$ and Nelson Marmiroli ${ }^{1,2,3}$ \\ 1 Department of Chemistry, Life Sciences and Environmental Sustainability, University of Parma, \\ Parco Area delle Scienze 11/A, 43124 Parma, Italy; nelson.marmiroli@unipr.it \\ 2 Interdepartmental Center SITEIA.PARMA, University of Parma, Parco Area delle Scienze 181/A, \\ 43124 Parma, Italy \\ 3 Italian National Interuniversity Consortium for Environmental Sciences (CINSA), University of Parma, \\ 43124 Parma, Italy \\ * Correspondence: marina.caldara@unipr.it
}

Citation: Caldara, M.; Marmiroli, N. Antimicrobial Properties of

Antidepressants and

Antipsychotics-Possibilities and Implications. Pharmaceuticals 2021, 14, 915. https://doi.org/10.3390/ ph14090915

Academic Editor: Maria Emília de Sousa

Received: 3 August 2021

Accepted: 8 September 2021

Published: 10 September 2021

Publisher's Note: MDPI stays neutral with regard to jurisdictional claims in published maps and institutional affiliations.

Copyright: (c) 2021 by the authors. Licensee MDPI, Basel, Switzerland. This article is an open access article distributed under the terms and conditions of the Creative Commons Attribution (CC BY) license (https:/ / creativecommons.org/licenses/by/ $4.0 /)$.

\begin{abstract}
The spreading of antibiotic resistance is responsible annually for over 700,000 deaths worldwide, and the prevision is that this number will increase exponentially. The identification of new antimicrobial treatments is a challenge that requires scientists all over the world to collaborate. Developing new drugs is an extremely long and costly process, but it could be paralleled by drug repositioning. The latter aims at identifying new clinical targets of an "old" drug that has already been tested, approved, and even marketed. This approach is very intriguing as it could reduce costs and speed up approval timelines, since data from preclinical studies and on pharmacokinetics, pharmacodynamics, and toxicity are already available. Antidepressants and antipsychotics have been described to inhibit planktonic and sessile growth of different yeasts and bacteria. The main findings in the field are discussed in this critical review, along with the description of the possible microbial targets of these molecules. Considering their antimicrobial activity, the manuscript highlights important implications that the administration of antidepressants and antipsychotics may have on the gut microbiome.
\end{abstract}

Keywords: antidepressants; antipsychotics; antimicrobials; drug repurposing

\section{Introduction}

Life-threatening microbes are more and more often displaying insensitivity to the commonly used therapeutics, up to the point that antimicrobial resistance is nowadays considered a global challenge. Indeed, this phenomenon is responsible annually for over 700,000 deaths worldwide, and it has been estimated that this number will increase exponentially [1,2]. E. coli, S. aureus, Enterococcus spp., P. aeruginosa, Kleibsiella spp., coagulasenegative Staphylococci, and Candida spp. are among the most frequently isolated microbes in health care-associated infections [3]. The development of new antimicrobial treatments is a challenge that scientists are approaching through global collaboration. Unfortunately, developing a new drug is an extremely expensive and long process that may take up to 17 years to be completed, and as a consequence, the discovery of new antibacterial agents has dropped by more than $50 \%$ [4], while the development of bacteria resistance has been increasing and very rapidly spreading. A parallel approach is drug repositioning, meaning the identification of new clinical targets for a drug already tested, approved, and even marketed [5]. This approach could cut costs and speed up the approval timelines, as data on preclinical studies, pharmacokinetics, pharmacodynamics, and toxicity have already been reported. Drug repositioning has been a very promising approach to finding possible therapies against COVID-19, leading to the identification of several possible treatments, such as antivirals (i.e., Lopinavir/Ritonavis, Remdesivir), immunosuppressors (i.e., Ruxolitinib, Tocilizumab, Eculizumab), and immunomodulators (i.e., Camostat, Interferons, 
Sargramostin). Currently, in the USA, more than 1000 clinical trials employing one of these drugs or a combination of them have been undertaken, and additional trials are ongoing in the rest of the world [6-8].

Different strategies can be applied to drug repurposing. First, non-antimicrobial approved drugs can be tested directly on cell-based models to sort out those displaying antimicrobial activity. This strategy can be undertaken even in a high-throughput mode [9-11]. It is a phenotype-based process and therefore it does not clarify the action mechanism of the new active drugs identified [12]. Once a drug and its microbiological target are clarified, it is possible to perform a screening on barcode mutant libraries in order to identify the relative molecular target. Here, thanks to chemogenomic profiling that follows haploinsufficiency profiling or homozygous profiling assays, pathways, or even proteins whose activity were selectively modified by the presence of the drug, are identified. This provides important information on the biological effects of the tested molecule [13-16]. For example, following this approach, the molecular target of psychoactive drugs, such as drofenine, clozapine, propiomazine, and metergoline, were suggested to be small ribosomal subunit and cytochrome c oxidase (COX17), the terminal component of the mitochondrial respiratory chain [17]. Chemogenomic profiling is a very powerful tool that can be applied to a limited number of microbes, as mutant libraries were only developed for the main model organisms (i.e., yeasts S. cerevisiae, C. albicans, S. pombe and bacteria E. coli and $P$. aeruginosa). An alternative approach to identifying the antimicrobial activity of a drug is based on screening for a clear phenotype in more clinically relevant environments, for example, on whole-animal systems [18]. In this case, other tests (biochemical, genomic, and computational) are necessary to identify the molecular target(s) [12]. Screenings can also be performed in silico by taking advantage of recent improvements of high-performance computers, artificial intelligence (AI) [19], and the availability of a vast amount of biological, chemical, and pharmacological data.

There are almost 50 drugs that have been approved to be used on new targets due to drug repositioning initiatives [2,20-22]. Among those, amphotericin B, a known antifungal, is now approved to be used on visceral leishmaniasis, while chlorcyclizine, usually used to treat allergic reactions, can be employed as an antiviral, and the antibacterial doxycycline could be employed against malaria [23-25]. The first-generation antipsychotic haloperidol can induce ferroptosis in hepatocellular carcinoma cells. Ferroptosis is connected with the accumulation of Reactive Oxygen Species (ROS), and in this condition, haloperidol increases the cellular concentrations of GSH and $\mathrm{Fe}^{2+}$ and lipid peroxidation. [26-28]. Haloperidol is now employed in cancer preclinical and clinical studies. The antidepressants fluoxetine has been found to be beneficial against COVID-19 infections [6]. Taking fluoxetine lowers the risks of intubation and death by reducing the "cytokine storm" $[29,30]$. Moreover, several groups have reported the capacity of antidepressants and antipsychotics to inhibit the growth of different microbes, many of which are related to healthcare-associated infections. Overall, repurposed drugs could be used alone or, even better, in association with known antimicrobials to potentiate their actions. The latter strategy allows lowering the drugs' concentration and diminishing their possible toxicity and, at the same time, maximizing their joint action and preventing antimicrobial resistance development [31]. This strategy was already proven successful [32-34]. These studies suggest that these molecules could be integrated into a drug repositioning pipeline. This review aims at listing all the available data, reporting the microbiological targets identified upon treatment and discussing these findings. More importantly, the novelty of this review is that it highlights some important implications that the use of antidepressants could have on the ecology of the human gut.

To identify all the relevant manuscripts for this perspective review, several bibliographic searches were undertaken from May to August 2021 on "PubMed", "Elsevier's Scopus", Web of Science Clarivate Analytics, and "Google Scholar". The searches included several different combinations of keywords (i.e., sertraline-antimicrobial, sertralinerepurposing, sertraline-fungi, SSRIs-bacteria, etc.). 


\section{Brief Overview of the Actions of Antidepressants and Antipsychotics}

Depression has been mainly correlated with alterations in the noradrenergic and serotonergic functions. The link between a lower activity of the serotonin pathways and the development of depression is almost 50 years old. Indeed, in the 1950s, it was found that iproniazide and imipramine could improve the condition of depressed people and later, it was found that iproniazide, a MonoAmine Oxidase Inhibitor (MAOI), and imipramine, a Tricyclic Antidepressant (TCA), were able to inhibit the reuptake of monoamines and had the capacity to increase the effect of serotonin at the synapses [35]. Since the discovery of the first MAOI and TCA, many more variant molecules were developed. The lack of specificity of these drugs causes several undesirable side effects including toxic ones. To overcome these problems, Selective Serotonin Reuptake Inhibitors (SSRIs) were developed, a discovery that improved the quality of life of patients suffering from depression, as SSRIs are more tolerated and safer than MAOIs and TCAs [35-37].

People suffering from psychotic behaviors (i.e., schizophrenic, aggressive, anxious, agitated behaviors) are mostly cured with neuroleptics and benzodiazepines [27,38-41]. These drugs act by blocking the dopamine receptors. These drugs act by: (a) blocking dopamine receptors, or (b) combining the inhibition of serotonin uptake and dopamine receptors, and producing side effects on cholinergic, histaminic, and adrenergic receptors [42,43] or also (c) by promoting the activity of the neurotransmitter gamma-aminobutyric acid [44] (GABA).

\section{Repurposing of Antidepressant and Antipsychotic Drugs}

Recent reports have shown that antidepressants may have a positive effect on other pathologies. Indeed, besides their "classical" use, TCAs and SSRIs were beneficial when administered to persons suffering from irritable bowel syndrome. The dose of antidepressants used to treat patients with irritable bowel syndrome is lower than the one employed to treat psychiatric disorders. With this lower dose, no effect on anxiety or depression were generally reported [45-47]. Moreover, desipramine and fluoxetine reduce the risk of colitis in animal models, even though these data have to be confirmed in clinical trials [46]. The SSRIs fluoxetine, paroxetine, sertraline, escitalopram, and citalopram have been proven to reduce several premenstrual syndrome symptoms, although in some cases, side effects have also been reported with a dose-depended relationship [48,49]. Interestingly, sertraline had also positive effects in women suffering from premenstrual syndrome and recurrent vulvovaginal candidiasis. Indeed, in these patients during the cure, no recurrent episodes of yeast infection were reported [48,50]. This effect is not surprising, as many antidepressants have been found to have a negative effect on the growth of Candida albicans (see Table 1). 


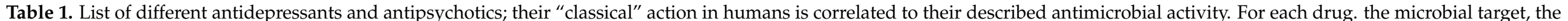

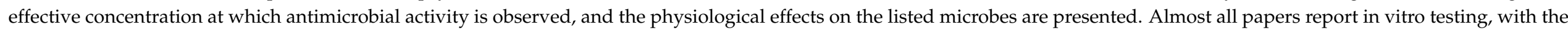
exception of [50-55], which report some in vivo testing.

\begin{tabular}{|c|c|c|c|c|}
\hline Drug & Microbial Target & $\begin{array}{c}\text { Concentration Effective on } \\
\text { Microbes }\end{array}$ & Physiological Effects on Microbes & References \\
\hline \multicolumn{5}{|c|}{ ANTIDEPRESSANTs-SSRIs } \\
\hline $\begin{array}{l}\text { Sertraline } \\
\text { (third generation of selective } \\
\text { serotonin reuptake inhibitors) }\end{array}$ & $\begin{array}{l}\text { C. albicans, C. glabrata, C. tropicalis, C. } \\
\text { parapsilosis, C. dubliniensis, C. krusei, } \\
\text { A. fumigatus, A. flavus, A. terreus, C. } \\
\text { neofromans, S. cerevisiae, A. baumanii, } \\
\text { H. influenzae, C. jejuni, H. pylori, S. } \\
\text { aureus, P. aeruginosa, S. epidermidis, E. } \\
\text { faecalis, C. difficile, B. fragilis, } \\
\text { Prevotella spp }\end{array}$ & $\begin{array}{c}9-775 \mu \mathrm{M} \\
(3-237 \mu \mathrm{g} / \mathrm{mL})\end{array}$ & $\begin{array}{l}\text { Fungicidal; inhibits hyphal elongation and } \\
\text { phospholipase activity, reduces secreted aspartyl } \\
\text { proteinases (SAP) production, inhibits fungal viability, } \\
\text { has antifungal and anti-biofilm effects, displays a } \\
\text { synergistic effect with fluconazole, causes } \\
\text { mitochondrial depolarization and cell membrane } \\
\text { damage, induces autophagy }\end{array}$ & {$[50,51,56-63]$} \\
\hline $\begin{array}{l}\text { Fluoxetine } \\
\text { (third generation of selective } \\
\text { serotonin reuptake inhibitors) }\end{array}$ & $\begin{array}{c}\text { C. albicans, E. coli } \\
\text { P. aeruginosa, S. aureus, } \\
\text { Coxsackievirus, E. coli, A. baumanii }\end{array}$ & $\begin{array}{c}130 \mu \mathrm{M}-13 \mathrm{mM} \\
(40-4000 \mu \mathrm{g} / \mathrm{mL})\end{array}$ & $\begin{array}{l}\text { Inhibits cell growth; promotes mitochondrial } \\
\text { depolarization and membrane damage; decreases } \\
\text { metabolic activity of mature biofilms; displays } \\
\text { synergistic interaction with azoles such as fluconazole, } \\
\text { downregulates SAP genes expression and extracellular } \\
\text { phospholipase activity, inhibits bacterial growth and } \\
\text { synergizes with antibiotics, reduces the synthesis of } \\
\text { viral RNA and proteins. }\end{array}$ & {$[52,56,58,64-67]$} \\
\hline $\begin{array}{c}\text { Paroxetine } \\
\text { (third generation of selective } \\
\text { serotonin reuptake inhibitors) }\end{array}$ & C. albicans, E. coli, A. baumanii & $\begin{array}{c}110-282 \mu \mathrm{M} \\
(40-101 \mu \mathrm{g} / \mathrm{mL})\end{array}$ & $\begin{array}{l}\text { Inhibits cell growth; promotes mitochondrial } \\
\text { depolarization and membrane damage in yeast, } \\
\text { inhibits bacterial growth. }\end{array}$ & {$[56,58,67-69]$} \\
\hline \multicolumn{5}{|c|}{ ANTIDEPRESSANTs-MAOIs } \\
\hline $\begin{array}{c}\text { Clorgyline } \\
\text { (MonoAmine Oxidase Inhibitor) }\end{array}$ & C. albicans, C. glabrata & $\begin{array}{c}5.1 \mu \mathrm{M} \\
(1.4 \mu \mathrm{g} / \mathrm{mL})\end{array}$ & $\begin{array}{l}\text { Broad-spectrum inhibitor of several } \\
\text { fungal efflux pumps, displays a synergistic interaction } \\
\text { with fluconazole }\end{array}$ & {$[56,70]$} \\
\hline $\begin{array}{c}\text { Phenelzine } \\
\text { (MonoAmine Oxidase Inhibitor) }\end{array}$ & Salmonella & $\begin{array}{c}30-100 \mu \mathrm{M} \\
(4-14 \mu \mathrm{g} / \mathrm{mL})\end{array}$ & Inhibits TYR oxidoreductase & {$[71]$} \\
\hline
\end{tabular}


Table 1. Cont.

\begin{tabular}{|c|c|c|c|c|}
\hline Drug & Microbial Target & $\begin{array}{c}\text { Concentration Effective on } \\
\text { Microbes }\end{array}$ & Physiological Effects on Microbes & References \\
\hline $\begin{array}{c}\text { Doxepin } \\
\text { (increases the levels of } \\
\text { norepinephrine, along with } \\
\text { blocking histamine, acetylcholine, } \\
\text { and serotonin) }\end{array}$ & $\begin{array}{l}\text { C. albicans, C. glabrata, C. parapsilosis, } \\
\text { C. krusei, C. utilis }\end{array}$ & $\begin{array}{c}716 \mu \mathrm{M} \\
(200 \mu \mathrm{g} / \mathrm{mL})\end{array}$ & $\begin{array}{l}\text { Inhibits hyphae and biofilm formation, kills cells in a } \\
\text { mature yeast biofilm }\end{array}$ & {$[72]$} \\
\hline $\begin{array}{l}\text { Imipramine } \\
\text { (increases the levels of serotonin and } \\
\text { norepinephrine and blocks some } \\
\text { serotonin, adrenergic, histamine, } \\
\text { and cholinergic receptors) }\end{array}$ & $\begin{array}{l}\text { C. albicans, C. glabrata } \\
\text { C. parapsilosis, C. krusei, C. utilis }\end{array}$ & $\begin{array}{c}142 \mu \mathrm{M} \\
(40 \mu \mathrm{g} / \mathrm{mL})\end{array}$ & $\begin{array}{l}\text { Inhibits hyphae and biofilm formation, kills cells in a } \\
\text { mature yeast biofilm }\end{array}$ & {$[72]$} \\
\hline $\begin{array}{c}\text { Nortryptiline } \\
\text { (blocks the reuptake of } \\
\text { norepinephrine, binds to } \\
\text { alpha-adrenergic, histaminergic, } \\
\text { and cholinergic receptors) }\end{array}$ & $\begin{array}{l}\text { C. albicans, C. glabrata, C. parapsilosis, } \\
\text { C. krusei, C. utilis }\end{array}$ & $\begin{array}{c}190 \mu \mathrm{M} \\
(50 \mu \mathrm{g} / \mathrm{mL})\end{array}$ & $\begin{array}{l}\text { Inhibits hyphae and biofilm formation, kills cells in a } \\
\text { mature biofilm, induces cell lysis, and displays } \\
\text { synergistic activity with amphotericin B }\end{array}$ & {$[72,73]$} \\
\hline $\begin{array}{l}\text { Amitriptyline } \\
\text { (Inhibits the reuptake of serotonin } \\
\text { and norepinephrine) }\end{array}$ & $\begin{array}{l}\text { Staphylococcus spp., Bacillus spp., } V \text {. } \\
\text { cholerae, Micrococcus spp, } L . \\
\text { sporogenes, Citrobacter spp. }\end{array}$ & $\begin{array}{c}36-722 \mu \mathrm{M} \\
(10-200 \mu \mathrm{g} / \mathrm{mL})\end{array}$ & Inhibits microbial growth & [53] \\
\hline $\begin{array}{l}\text { Amoxapine } \\
\text { (Reduces the uptake of serotonin } \\
\text { and noradrenaline) }\end{array}$ & Salmonella, Y. pestis & $\begin{array}{c}1-100 \mu \mathrm{M} \\
(0.3-30 \mu \mathrm{g} / \mathrm{mL})\end{array}$ & $\begin{array}{l}\text { Inhibits GUS-mediated hydrolysis of d-glucuronides, } \\
\text { reduces cytotoxicity in murine macrophages }\end{array}$ & {$[54,71]$} \\
\hline \multicolumn{5}{|c|}{ ANTIPSYCHOTIC-NEUROLEPTIC } \\
\hline $\begin{array}{c}\text { Aripiprazole } \\
\text { (partial agonist of serotonin and } \\
\text { dopamine receptors) }\end{array}$ & C. albicans & $\begin{array}{c}11-111 \mu \mathrm{M} \\
(5-50 \mu \mathrm{g} / \mathrm{mL})\end{array}$ & $\begin{array}{l}\text { At low doses, it inhibits biofilm formation, as well as } \\
\text { yeast-to-hyphal transition and flocculation; at high } \\
\text { doses, disrupts lipid rafts, induces membrane damage }\end{array}$ & [74] \\
\hline $\begin{array}{l}\text { Bromperidol } \\
\text { (antagonist of the dopamine } \\
\text { receptor) }\end{array}$ & $\begin{array}{c}\text { Mycobacterium smegmatis, } M . \\
\text { tubercolosis, C. albicans, C. glabrata, } A . \\
\text { terreus }\end{array}$ & $\begin{array}{c}119-142 \mu \mathrm{M} \\
(50-60 \mu \mathrm{g} / \mathrm{mL})\end{array}$ & $\begin{array}{c}\text { Acts synergistically with spectinomycin on } \\
\text { Mycobacterium, is bactericidal, interacts positively with } \\
\text { azoles }\end{array}$ & {$[55,75]$} \\
\hline \multicolumn{5}{|c|}{ ANTIPSYCHOTIC-BENZODIAZEPINE } \\
\hline
\end{tabular}


Table 1. Cont.

\begin{tabular}{|c|c|c|c|c|}
\hline Drug & Microbial Target & $\begin{array}{c}\text { Concentration Effective on } \\
\text { Microbes }\end{array}$ & Physiological Effects on Microbes & References \\
\hline $\begin{array}{l}\text { Diazepam } \\
\text { (increases the effect of the } \\
\text { neurotransmitter GABA) }\end{array}$ & C. albicans & $\begin{array}{c}108 \mu \mathrm{M}-14 \mathrm{mM} \\
(31.25-4000 \mu \mathrm{g} / \mathrm{mL})\end{array}$ & Inhibits growth, hyphae formation, and biofilm growth & [76] \\
\hline $\begin{array}{c}\text { Lorazepam } \\
\text { (enhancer of the effect of the } \\
\text { inhibitory neurotransmitter } \\
\text { gamma-aminobutyric acid on } \\
\text { GABA receptors) }\end{array}$ & C. albicans & $\begin{array}{c}96 \mu \mathrm{M}-12 \mathrm{mM} \\
(31.25-4000 \mu \mathrm{g} / \mathrm{mL})\end{array}$ & Inhibits growth, hyphae formation, and biofilm growth & [76] \\
\hline $\begin{array}{c}\text { Midazolam } \\
\text { (promotes the action of GABA) }\end{array}$ & $\begin{array}{l}\text { C. albicans, S. aureus, E. faecalis, E. } \\
\text { coli, P. aeruginosa, A. baumanii }\end{array}$ & $\begin{array}{c}95 \mu \mathrm{M}-12 \mathrm{mM} \\
(31.25-4000 \mu \mathrm{g} / \mathrm{mL})\end{array}$ & $\begin{array}{l}\text { Inhibits growth, hyphae formation, and biofilm } \\
\text { growth, inhibits bacterial growth }\end{array}$ & [76-78] \\
\hline \multicolumn{5}{|c|}{ ANTIPSYCHOTIC-ATYPICAL } \\
\hline $\begin{array}{c}\text { Zotepine } \\
\text { (High affinity to dopamine } \\
\text { receptors, affects serotonin } \\
\text { receptors, its active metabolite, } \\
\text { norzotepine, serves as a potent } \\
\text { norepinephrine reuptake inhibitor) }\end{array}$ & C. albicans & $\begin{array}{c}0.1-40 \mu \mathrm{M} \\
(0.03-12 \mu \mathrm{g} / \mathrm{mL})\end{array}$ & Inhibits biofilm development & [10] \\
\hline
\end{tabular}




\section{Candida albicans, a Common Target of Antidepressants and Antipsychotics}

Many antidepressants and antipsychotics showed to be effective, at least in vitro, against several types of fungi such as A. fumigatus, A. flavus, A. terreus, and C. neoformans, and, especially, against Candida spp., particularly C. albicans (see Table 1 for details). Candida albicans is a member of a healthy microbiota, colonizing the gastrointestinal tract, skin, and oral cavity [79-81]. Unfortunately, alterations in the host immune response or its microbiota or changes in the environment can stimulate the growth of $C$. albicans, a phenomenon that can cause thrush, vaginal yeast infections, diaper rash, and even more serious infections especially in immunocompromised individuals [82]. Moreover, this yeast can easily colonize implanted medical devices thanks to its capacity to form stable biofilms, a contamination that could lead to bloodstream infections and even invasive systemic infections of organs or tissues [83]. Biofilm growth leads to inherent resistance to antimicrobial agents, a phenomenon connected with the increased expression of efflux pumps, the formation of the extracellular matrix, and the presence of persister cells $[84,85]$. Antifungal drugs used nowadays target ergosterol biosynthesis or 1,3- $\beta$-D-glucan synthesis. With the development of resistance and the fact that high doses of antimicrobials can cause liver and kidney damages [86], new molecules active against $C$. albicans, preventing biofilm formation or destroying its integrity, are certainly needed $[87,88]$. Therefore, the promising antimicrobial capacity of antidepressants and antipsychotics should be further investigated. In parallel, as this yeast is considered a model organism, the identification of the mechanism of action of a new antimicrobial is aided by the possibility to perform chemogenomics studies, as mutant libraries are available, as well as to perform DNA transformation, epitope tagging, and immunoprecipitation, to name a few.

\section{Possible Antimicrobial Activities of Antidepressants and Antipsychotics}

All three classes of antidepressants and many of the antipsychotics have antimicrobial activity (see Table 1); interestingly, most of the targeted microbes are isolated in healthcareassociated infections. Often, the reported biological effects following drug treatments are similar for many of the tested microbes. By looking at Table 1, it is clear that the consequences of the treatments have been described especially in Candida spp. In this yeast, antidepressants or antipsychotics often negatively influence key virulence factors, a phenomenon with negative consequences on the capacity of pathogenic fungi to attack the human body. Indeed, frequent drug targets are the formation of hyphae, which is one of the first steps in biofilm formation, the enzymes aspartyl proteinases, key virulence factors able to degrade many human proteins (i.e., mucin, immune system molecules, endothelial cell proteins, and coagulation factors), and phospholipase enzymes, proteins able to break the ester bonds of phospholipids, inducing cell lysis [89]. Active proteinase and phospholipase support the process of pathogenesis [90]. Many drugs have been shown to disrupt cell membrane's integrity, sometimes also acting at the level of lipid rafts. The latter are areas of the membrane that are particularly rich in sphingolipids and are involved in membrane trafficking, control of $\mathrm{Na}^{+} / \mathrm{K}^{+}$balance, and $\mathrm{pH}$ homeostasis [91]. Damage to the membranes can induce cell lysis or autophagy, the latter being a self-degrading process that can be also be directly induced by some antifungals [92]. Autophagy is correlated with mitochondria depolarization, another effect often observed when yeasts are treated with antidepressants and antipsychotics. The working concentrations reported in Table 1 are within the same range of those of the known antimicrobials and antibiotics (for $C$. albicans, the $\mathrm{MIC}_{90}$ of fluconazole is around $3 \mu \mathrm{M}$ ). Many works reported that these drugs work synergistically with azoles, especially fluconazole, and with amphotericin B. All of the combinations display a fractional inhibitory index (FICI or FIX) well below 0.5 [93]. This is a positive outcome, as these synergistic combinations could reduce the antibiotic concentrations used to treat an infection, in parallel reducing the toxic side effects and preventing the development of resistance [31].

Among the SSRIs, sertraline is the most studied, found to be active in some cases already at the concentration of $9 \mu \mathrm{M}$. This drug was tested on more than 20 microbes includ- 
ing yeast and bacteria. On yeast, and especially on C. albicans, it inhibits virulence factors such as hyphal formation and the secretion of aspartyl proteinases, kills yeast, and inhibits biofilm formation. Moreover, this drug works synergistically with fluconazole [50,51,58]. In bacteria, sertraline was shown to inhibit growth and to work synergistically with other antibiotics, but no further details have been reported [60-63]. To our knowledge, sertraline is also the only drug being employed as an antifungal in humans, specifically, against cryptococcal meningitis. Sertraline was initially demonstrated to be able to potentiate the action of azoles against cryptococcal microbes [60]; later, it was tested in a Phase II study [94] and a follow-up Phase III study in HIV patients infected by this fungus, but with no convincing results [95].

Fluoxetine, an SSRI, was found to be active against bacteria, fungi [50,56,64,67], and, interestingly, even a virus. Indeed, this drug was able to inhibit the viral RNA and proteins of Coxsackievirus [66]. The latter is an enterovirus, a small non-enveloped RNA virus, member of a genus responsible for different life-threatening conditions such as encephalitis or myocarditis [96]. Clorgyline, a MAOI, is active against C. albicans and C. glabrata where it inhibits efflux pumps and positively interacts with fluconazole [56,70]. A second MAOI, phenelzine, was found instead to be active against Salmonella [71]. Works based on TCAs showed that this class of molecules was active against Candida spp., where they inhibited hyphal formation, lysed the cells, and killed them even in a mature biofilm [72,73]. Moreover, the TCA amoxapine is active against Salmonella and Y. pestis [54,71]. Interestingly, some TCAs and the antipsychotic thioridazine are capable to resensitize methicillin-resistant $S$. aureus (MRSA) to $\beta$-lactam [97-99]. This is relevant, as it opens the possibility to use this drug, alone or in combination with known antibiotics, to treat resistant bacteria.

The neuroleptics aripiprazole and bromperidol can inhibit biofilm formation by Candida spp., but the second was found to work synergistically with spectinomycin to inhibit the growth of Mycobacterium smegmatis and M. tuberculosis [55,75]. Benzodiazepines are active against $C$. albicans and can inhibit biofilm formation; they are also active against $S$. aureus, E. faecalis, E. coli, P. aeruginosa, and A. baumanii [10,76-78].

\section{Possible Mechanisms of Action}

Antidepressants and antipsychotics display antimicrobial activity on a wide range of microbes, as reported in Table 1 . However, the examined reports do not include specific details on their mechanism of action and molecular targets. The following paragraphs summarize what is known so far on this topic.

\subsection{Inhibition of Efflux Pumps}

A direct target of SSRIs, and partially of some TCAs, is the human Serotonin Transporter, a membrane-bound $\mathrm{Na}^{+}$-dependent solute carrier with 12 putative transmembrane domains. Its action allows the import of serotonin inside cells, and antidepressants inhibit this action. It has been suggested that, in microbes, the same molecules lower the activity of other proteins transporters such as xenobiotic efflux pumps (Figure 1). Indeed, overexpression of the efflux pumps Cdr1, Cdr2, or Mdr1 is a common way adopted by $C$. albicans to detoxify itself from xenobiotics [100]; P. aeruginosa does the same with MexABOprM and MexXY-OprM [101], and S. enterica serovar Typhimurium increases the levels of AcrB to excrete $\beta$-lactam antibiotics [102]. Inhibiting the removal of a toxic compound, such as an antibiotic, would therefore allow the latter to exert its action within cells. This idea is supported by the observation that the activity of C. albicans transporters overexpressed in multi-drug-resistant strains and expressed in S. cerevisiae, can be inhibited by the antidepressants clorgyline [70].

\subsection{Inhibition of Mitochondria Activity}

As reported in several works, the action of antidepressants and neuroleptics in microbes involves different biological processes, and it is suggested that several different components could be the target of these drugs [61]. Indeed, treatment of a C. albicans 
mutants library with nortriptyline identified mutants that are specifically sensitive or tolerant to this drug and others that share the same phenotype when treated with common antifungals [73]. The work suggests that mitochondria are one of the targets of nortriptyline (Figure 1), although it is not clear which function, carried out by this organelle (i.e., ATP production and oxidative phosphorylation, maintenance of the redox state, cell survival or apoptosis induction, lipid peroxidation), is affected. Inhibition of mitochondrial activity is displayed also when yeasts are treated with other central nervous systems drugs [103].

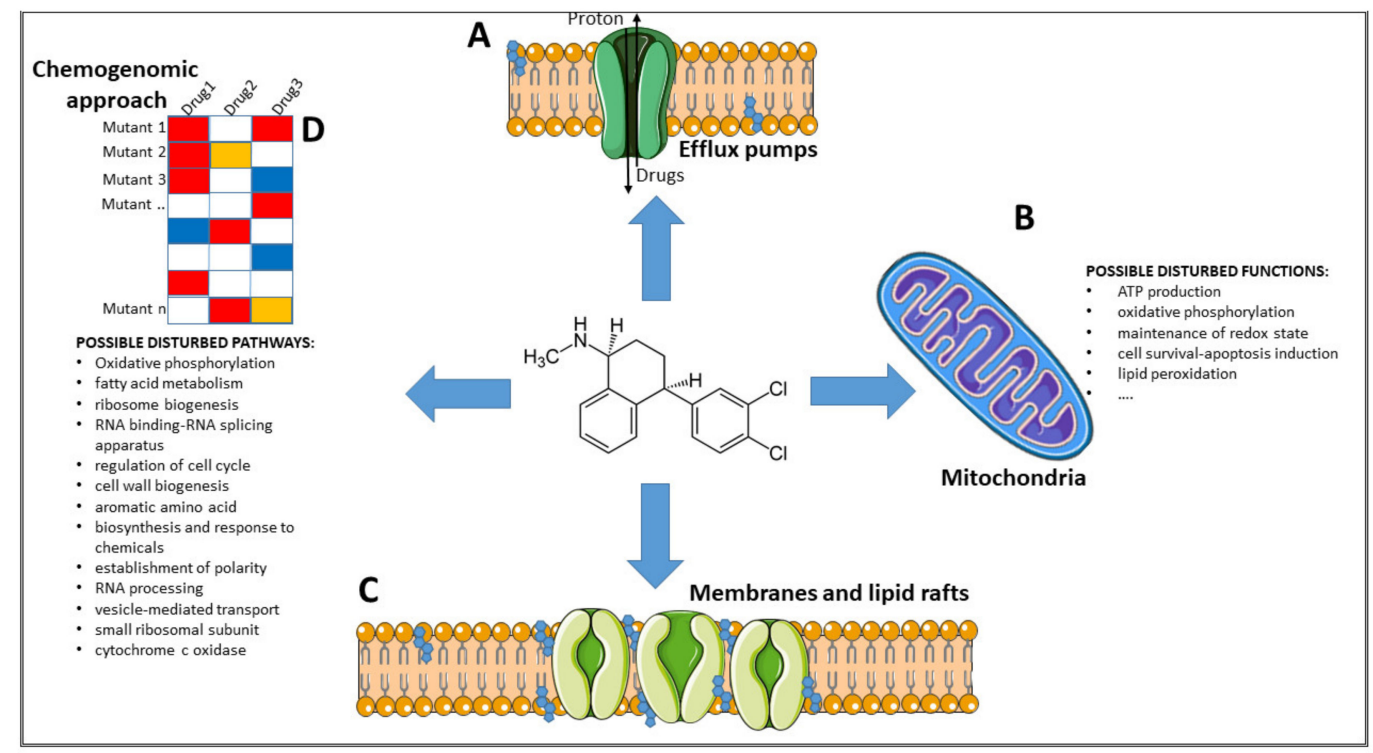

Figure 1. Proposed mechanisms of action. Few are the mechanisms of action suggested for antidepressants and antipsychotics. They involve inhibition of efflux pumps (A), disturbance of mitochondria (B) (a list of possible functions that can be affected in the organelle are reported), and disruption of the integrity of membranes or lipid rafts $(\mathbf{C})$. Moreover, with chemogenomics and the use of barcoded mutants (D), pathways and molecular targets of different psychoactive drugs were discovered in the model organisms S. cerevisiae and C. albicans. Future studies will need to confirm these findings. Part of the graph was made using https:/ / smart.servier.com/ (accessed on 1 July 2021).

\subsection{Interference with Membrane Integrity}

It has been suggested that neuroleptics such as aripiprazole can interfere with Lanosterol 14 alpha-demethylase or CYP51, similarly to azoles, disrupting lipid rafts and inducing membrane damage [74]. The antipsychotic phenothiazine and the antidepressant nortriptyline have also been reported to disrupt cell membranes [72,104,105]. As mentioned earlier, TCAs and thioridazine, an antipsychotic, are able to reverse the resistance of MRSA to $\beta$-lactam. It has been reported that do so, TCAs act by repressing the expression of $\beta$-lactam resistance genes, while thioridazine acts by inhibiting the expression of genes involved in cell wall biosynthesis [98,99].

\subsection{Possible Disturbed Pathways}

Chemogenomic profiling with a haploinsufficiency approach focused on C. albicans mutants identified the following processes and systems as possible targets of nortriptyline: oxidative phosphorylation, fatty acid metabolism, ribosome biogenesis and machinery, RNA binding, and the RNA splicing apparatus $[73,106]$. Following the same approach, the targets of the TCA chlorpromazine in $S$. cerevisiae were suggested to be the regulation of cell cycle, cell wall biogenesis, aromatic amino acid biosynthesis, and response to chemicals [106]. With the same approach, Ericson et al., showed that in S. cerevisiae, the most notable effect of fluoxetine was on the establishment of polarity, that of paroxetine was RNA processing, and that of sertraline was vesicle-mediated transport [107]. Hillenmeyer et al. reported that, in the same microbe, the small ribosomal subunit and cytochrome c oxidase 
are the targets of psychoactive drugs [17]. The heterocyclic compounds acridines have been widely used also as antibacterial agents, due to their capacity to bind DNA and interfere with the activity of the enzymes topoisomerase I and II [108]. It has been suggested that two or more benzene rings, a common feature of acridine and of some antidepressants and antipsychotics (see Figure 2), could be among the key functional groups for antimicrobial activity [53].

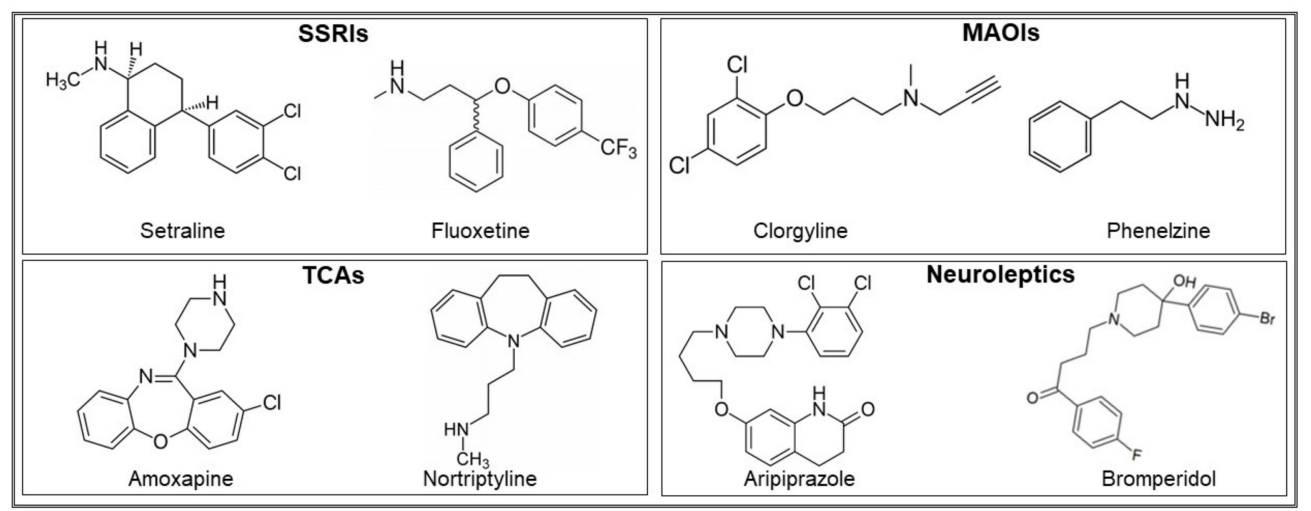

Figure 2. Chemical structure of some SSRIs, MAOIs, TCAs, and neuroleptics which highlights similarities and differences between the different chemicals.

\section{Implications of the Antimicrobial Activity of Antidepressants in Human Gut Ecology}

In the previous sections, we described how antidepressants and antipsychotics negatively influence the growth and physiology of different microbes, both bacteria and fungi. This observation has broader therapeutic implications, as many microbes are symbionts or opportunistic microorganisms in the human body, including skin and gut.

Recently, phenelzine, desipramine, venlafaxine, bupropion, aripiprazole, and (S)citolapram have been tested for this property also in isolated commensal bacteria. The results have shown that these drugs can inhibit the growth of phyla that are dominant within the human microbiota such as Bifidobacterium animalis and Bacteroides fragilis [109]. This work strongly suggests the capacity of antidepressants to act as antimicrobials also on beneficial microbes residing in the human gut.

It is known that the gut forms a two-direction communication system with the brain, forming the so-called "gut-brain axis". Serotonin is a neurotransmitter whose concentration is fine-tuned in our body. Indeed, low levels of this neurotransmitter have been correlated with the development of depression, while high levels have been linked also to colitis $[110,111]$. The gut microbiota was implicated in regulating the levels of serotonin [110], and some of the microbes residing in the gut can produce serotonin (i.e., Lactococcus lactis subsp. cremoris, L. lactis subsp. Lactis, Lactobacillus plantarum, Streptococcus thermophilus, E. coli K-12, Morganella morganii, Klebsiella pneumonia) [110,112,113]. So far, the possibility that modifications of the gut microbiota could negatively influence serotonergic signaling has only been suggested in pre-clinical studies, as data from clinical trials are still very limited [110].

Moreover, it was reported that people suffering from depression frequently displayed an altered gut microbiota, with a decreased richness and diversity of species [114]. For example, Lin et al. showed that depressed patients display a different gut composition with more bacteria of the phylum Firmicutes, less Bacteroidetes, and more bacteria of the genera Prevotella, Klebsiella, and Streptococcus [115], while Naseribafrouei et al. showed that Bacteroidales are increased in depressed patients who have a decreased level of the Lachnospiraceae family (a more exhaustive list can be found in a recent review [116]). It was reported that the frequent use of antibiotics was correlated with an increased risk of developing depression or anxiety [65]. 
Probiotics have been recently tested to re-establish a healthy microbial status, due to their ability to balance the dysbiosis created under the depressive state [117]. As an example, the psychobiotic B. breve A-1 improved depressive symptoms in patients with schizophrenia [118], while a mixture of L. acidophilus, L. casei, and Bifidobacterium bifidum was beneficial on depressive symptoms [119]. At the moment, many psychobiotics, being them prebiotics, probiotics, postbiotics, and even single molecules involved in the gut microbial signaling, are being tested to identify any possible therapeutic benefits $[116,120]$.

Previous reports showed that patients suffering from depression display microbial dysbiosis. As many of these studies were conducted in patients with depression, who were often being treated for it at the time of the analyses, more studies are necessary to describe the gut microbiome before and after medical treatments, so to understand if and how antidepressants could influence dysbiosis. Moreover, taking antidepressants could affect specifically those microbial strains able to produce serotonin, possibly adding a negative factor to the overall compromised health system, which is an extra factor to considered. A recent hypothesis suggests that shifts in the gut microbial composition upregulate proinflammatory pathways leading to the worsening of depressive symptoms, a theory that implicates also the immune system in this complex balance [116].

\section{Conclusions}

The development of antibiotic resistance is a global threat. To try to solve this problem, new antibiotics or antimicrobials should be developed, a task that has to face many different challenges. As a complement to new drug discovery, drug repositioning could be investigated. In this review, the antimicrobial capacity of antidepressants and antipsychotics identified by different laboratories has been summarized. Many of these drugs have been found to disturb the integrity of the cell membrane, mitochondria activity, and critical Candida spp. virulence factors (i.e., hyphae formation, SAP, and phospholipase enzymes). Less is known on their effects on bacteria. The premises are encouraging; however, more aspects need to be investigated in depth before some of these drugs could be labelled as true antimicrobials. To reach this point, it will be necessary to:

- Clearly identify the microbial molecular target(s) of each potential new drug, especially in bacteria

- Describe the connection between the administration of these drugs and their influence on the gut microbiome, after a short and/or prolonged administration, and in the frame of the gut-brain axis

- Pinpoint the concentration at which these molecules would be active as antimicrobials, a parameter that should be equal to, or even lower than, the one used to treat the original disease

- Identify new uses, such as investigate the possibility of topical application

- Test whether, when combined with other known antimicrobials, they potentiate the overall effects of the latter and at the same time, allow lowering antimicrobials' global concentration and their possible correlated toxic effect

- Better understand which of these drugs may have an acridine-like effect on DNA and which are more active at the level of mitochondrial functions.

Author Contributions: Conceptualization, M.C. and N.M.; writing-original draft preparation and editing, M.C. and N.M.; funding acquisition, N.M. All authors have read and agreed to the published version of the manuscript.

Funding: This research received funding from CINSA (Italian National Interuniversity Consortium for Environmental Sciences).

Institutional Review Board Statement: Not applicable.

Informed Consent Statement: Not applicable.

Data Availability Statement: Data sharing not applicable. 
Acknowledgments: The authors wish to acknowledge F. Tedeschi and P.P. Puglisi who prompted the interest in studying the antimicrobial activity of central nervous systems drugs.

Conflicts of Interest: The authors declare no conflict of interest.

\section{References}

1. Yssel, A.E.J.; Vanderleyden, J.; Steenackers, H.P. Repurposing of nucleoside- and nucleobase-derivative drugs as antibiotics and biofilm inhibitors. J. Antimicrob. Chemother. 2017, 72, 2326-2333. [CrossRef]

2. Farha, M.A.; Brown, E.D. Drug repurposing for antimicrobial discovery. Nat. Microbiol. 2019, 4, 565-577. [CrossRef]

3. Magill, S.S.; Edwards, J.R.; Bamberg, W.; Beldavs, Z.G.; Dumyati, G.; Kainer, M.A.; Lynfield, R.; Maloney, M.; Mcallister-Hollod, L.; Nadle, J.; et al. Multistate Point-Prevalence Survey of Health Care-Associated Infections for the Emerging Infections Program Healthcare-Associated Infections and Antimicrobial Use Prevalence Survey Team*. N. Engl. J. Med. 2014, 370, 1198-1208. [CrossRef] [PubMed]

4. $\quad$ Spellberg, B.; Powers, J.H.; Brass, E.P.; Miller, L.G.; Edwards, J.E. Trends in antimicrobial drug development: Implications for the future. Clin. Infect. Dis. 2004, 38, 1279-1286. [CrossRef] [PubMed]

5. Konreddy, A.K.; Rani, G.U.; Lee, K.; Choi, Y. Recent Drug-Repurposing-Driven Advances in the Discovery of Novel Antibiotics. Curr. Med. Chem. 2018, 26, 5363-5388. [CrossRef] [PubMed]

6. Altay, O.; Mohammadi, E.; Lam, S.; Turkez, H.; Boren, J.; Nielsen, J.; Uhlen, M.; Mardinoglu, A. Current Status of COVID-19 Therapies and Drug Repositioning Applications. iScience 2020, 23, 101303. [CrossRef] [PubMed]

7. Viveiros Rosa, S.G.; Santos, W.C. Clinical trials on drug repositioning for COVID-19 treatment. Rev. Panam. Salud Publica/Pan Am. J. Public Health 2020, 44, e40. [CrossRef]

8. Gysi, D.M.; Do Valle, Í.; Zitnik, M.; Ameli, A.; Gan, X.; Varol, O.; Ghiassian, S.D.; Patten, J.J.; Davey, R.A.; Loscalzo, J.; et al. Network medicine framework for identifying drug-repurposing opportunities for COVID-19. Proc. Natl. Acad. Sci. USA 2021, 118, 1-11. [CrossRef]

9. Krysan, D.J.; Didone, L. A high-throughput screening assay for small molecules that disrupt yeast cell integrity. J. Biomol. Screen. 2008, 13, 657-664. [CrossRef]

10. Siles, S.A.; Srinivasan, A.; Pierce, C.G.; Lopez-Ribot, J.L.; Ramasubramanian, A.K. High-throughput screening of a collection of known pharmacologically active small compounds for identification of candida albicans biofilm inhibitors. Antimicrob. Agents Chemother. 2013, 57, 3681-3687. [CrossRef]

11. Jacobs, A.C.; DiDone, L.; Jobson, J.; Sofia, M.K.; Krysan, D.; Dunman, P.M. Adenylate kinase release as a high-throughputscreening-compatible reporter of bacterial lysis for identification of antibacterial agents. Antimicrob. Agents Chemother. 2013, 57, 26-36. [CrossRef]

12. Schenone, M.; Dančík, V.; Wagner, B.K.; Clemons, P.A. Target identification and mechanism of action in chemical biology and drug discovery. Nat. Chem. Biol. 2013, 9, 232-240. [CrossRef]

13. Giaever, G.; Nislow, C. The yeast deletion collection: A decade of functional genomics. Genetics 2014, 197, 451-465. [CrossRef] [PubMed]

14. Giaever, G.; Shoemaker, D.D.; Jones, T.W.; Liang, H.; Winzeler, E.A.; Astromoff, A.; Davis, R.W. Genomic profiling of drug sensitivities via induced haploinsufficiency. Nat. Genet. 1999, 21, 278-283. [CrossRef]

15. Hillenmeyer, M.E.; Fung, E.; Wildenhain, J.; Pierce, S.E.; Hoon, S.; Lee, W.; Proctor, M.; Onge, R.P.S.; Tyers, M.; Koller, D.; et al. The chemical genomic portrait of yeast: Uncovering a phenotype for all genes. Science 2008, 320, 362-365. [CrossRef] [PubMed]

16. Roemer, T.; Jiang, B.; Davison, J.; Ketela, T.; Veillette, K.; Breton, A.; Tandia, F.; Linteau, A.; Sillaots, S.; Marta, C.; et al. Large-scale essential gene identification in Candida albicans and applications to antifungal drug discovery. Mol. Microbiol. 2003, 50, $167-181$. [CrossRef]

17. Hillenmeyer, M.E.; Ericson, E.; Davis, R.W.; Nislow, C.; Koller, D.; Giaever, G. Systematic analysis of genome-wide fitness data in yeast reveals novel gene function and drug action. Genome Biol. 2010, 11, 1-17. [CrossRef] [PubMed]

18. Farha, M.A.; Brown, E.D. Unconventional screening approaches for antibiotic discovery. Ann. N. Y. Acad. Sci. 2015, 1354, 54-66. [CrossRef] [PubMed]

19. Koromina, M.; Pandi, M.T.; Patrinos, G.P. Rethinking Drug Repositioning and Development with Artificial Intelligence, Machine Learning, and Omics. Omi. A J. Integr. Biol. 2019, 23, 539-548. [CrossRef]

20. Ashburn, T.T.; Thor, K.B. Drug repositioning: Identifying and developing new uses for existing drugs. Nat. Rev. Drug Discov. 2004, 3, 673-683. [CrossRef]

21. Chong, C.R.; Sullivan, D.J. New uses for old drugs. Nature 2007, 448, 645-646. [CrossRef]

22. Foletto, V.S.; da Rosa, T.F.; Serafin, M.B.; Bottega, A.; Hörner, R. Repositioning of non-antibiotic drugs as an alternative to microbial resistance: A systematic review. Int. J. Antimicrob. Agents 2021, 58, 106380. [CrossRef]

23. He, S.; Lin, B.; Chu, V.; Hu, Z.; Hu, X.; Xiao, J.; Wang, A.Q.; Schweitzer, C.J.; Li, Q.; Imamura, M.; et al. Repurposing of the antihistamine chlorcyclizine and related compounds for treatment of hepatitis C virus infection. Sci. Transl. Med. 2015, 7, 282ra49. [CrossRef] [PubMed]

24. Meyerhoff, A.U.S. Food and Drug Administration approval of AmBisome (liposomal amphotericin B) for treatment of visceral leishmaniasis. Clin. Infect. Dis. 1999, 28, 42-48. [CrossRef] [PubMed] 
25. Tan, K.R.; Magill, A.J.; Parise, M.E.; Arguin, P.M. Doxycycline for malaria chemoprophylaxis and treatment: Report from the CDC expert meeting on malaria chemoprophylaxis. Am. J. Trop. Med. Hyg. 2011, 84, 517-531. [CrossRef] [PubMed]

26. Bai, T.; Wang, S.; Zhao, Y.; Zhu, R.; Wang, W.; Sun, Y. Haloperidol, a sigma receptor 1 antagonist, promotes ferroptosis in hepatocellular carcinoma cells. Biochem. Biophys. Res. Commun. 2017, 491, 919-925. [CrossRef]

27. Dold, M.; Samara, M.T.; Li, C.; Tardy, M.; Leucht, S. Haloperidol versus first-generation antipsychotics for the treatment of schizophrenia and other psychotic disorders. Cochrane Database Syst. Rev. 2015, 1, CD009831. [CrossRef]

28. Georgiadis, M.O.; Karoutzou, O.; Foscolos, A.S.; Papanastasiou, I. Sigma receptor $(\sigma R)$ ligands with antiproliferative and anticancer activity. Molecules 2017, 22, 1408. [CrossRef]

29. Hoertel, N.; Sánchez-Rico, M.; Vernet, R.; Beeker, N.; Jannot, A.S.; Neuraz, A.; Salamanca, E.; Paris, N.; Daniel, C.; Gramfort, A.; et al. Association between antidepressant use and reduced risk of intubation or death in hospitalized patients with COVID-19: Results from an observational study. Mol. Psychiatry 2021, 1-14. [CrossRef]

30. Creeden, J.F.; Imami, A.S.; Eby, H.M.; Gillman, C.; Becker, K.N.; Reigle, J.; Andari, E.; Pan, Z.K.; O'Donovan, S.M.; McCullumsmith, R.E.; et al. Fluoxetine as an anti-inflammatory therapy in SARS-CoV-2 infection. Biomed. Pharmacother. 2021, 138, 111437. [CrossRef] [PubMed]

31. Peyclit, L.; Baron, S.A.; Rolain, J.M. Drug repurposing to fight colistin and carbapenem-resistant bacteria. Front. Cell. Infect. Microbiol. 2019, 9, 193. [CrossRef]

32. Mukherjee, D.; Wu, M.L.; Teo, J.W.P.; Dick, T. Vancomycin and clarithromycin show synergy against Mycobacterium abscessus in vitro. Antimicrob. Agents Chemother. 2017, 61, e01298-17. [CrossRef]

33. Sun, W.; Weingarten, R.A.; Xu, M.; Southall, N.; Dai, S.; Shinn, P.; Sanderson, P.E.; Williamson, P.R.; Frank, K.M.; Zheng, W. Rapid antimicrobial susceptibility test for identification of new therapeutics and drug combinations against multidrug-resistant bacteria. Emerg. Microbes Infect. 2016, 5, 1-11. [CrossRef] [PubMed]

34. Yu, W.; Shen, P.; Bao, Z.; Zhou, K.; Zheng, B.; Ji, J.; Guo, L.; Huang, C.; Xiao, Y. In vitro antibacterial activity of fosfomycin combined with other antimicrobials against KPC-producing Klebsiella pneumoniae. Int. J. Antimicrob. Agents 2017, 50, $237-241$. [CrossRef] [PubMed]

35. Dell'Osso, L.; Carmassi, C.; Mucci, F.; Marazziti, D. Depression, Serotonin and Tryptophan. Curr. Pharm. Des. 2016, 22, 949-954. [CrossRef]

36. Cowen, P.J.; Browning, M. What has serotonin to do with depression? World Psychiatry 2015, 14, 158-160. [CrossRef] [PubMed]

37. Cowen, P.J. Serotonin and depression: Pathophysiological mechanism or marketing myth? Trends Pharmacol. Sci. 2008, 29, 433-436. [CrossRef]

38. Brasseur, R. Clinical trial with bromperidol in psychotic states. Acta Psychiatr. Belg. 1978, 78, 110-117.

39. Nestoros, J.N.; Suranyl-Cadotte, B.E.; Spees, R.C.; Schwartz, G.; Vasavan Nair, N.P. Diazepam in high doses is effective in schizophrenia. Prog. Neuropsychopharmacol. Biol. Psychiatry 1982, 6, 513-516. [CrossRef]

40. Currier, G.W.; Chou, J.C.Y.; Feifel, D.; Bossie, C.A.; Turkoz, I.; Mahmoud, R.A.; Gharabawi, G.M. Acute treatment of psychotic agitation: A randomized comparison of oral treatment with risperidone and lorazepam versus intramuscular treatment with haloperidol and lorazepam. J. Clin. Psychiatry 2004, 65, 386-394. [CrossRef]

41. Kousgaard, S.J.; Licht, R.W.; Nielsen, R.E. Effects of Intramuscular Midazolam and Lorazepam on Acute Agitation in Non-Elderly Subjects-A Systematic Review. Pharmacopsychiatry 2017, 50, 129-135. [CrossRef]

42. Khan, H.J.; Rohondia, S.O.; Othman Ahmed, Z.S.; Zalavadiya, N.; Dou, Q.P. Increasing opportunities of drug repurposing for treating breast cancer by the integration of molecular, histological, and systemic approaches. In Drug Repurposing in Cancer Therapy; Elsevier Inc.: Amsterdam, The Netherlands, 2020; pp. 121-172.

43. Macdonald, G.J.; Bartolomé, J.M. A decade of progress in the discovery and development of "atypical" antipsychotics. In Progress in Medicinal Chemistry; Elsevier B.V.: Amsterdam, The Netherlands, 2010; Volume 49, pp. 37-80; ISBN 9780123812926.

44. Włodarczyk, A.; Szarmach, J.; Cubała, W.J.; Wiglusz, M.S. Benzodiazepines in combination with antipsychotic drugs for schizophrenia: GABA-ergic targeted therapy. Psychiatr. Danub. 2017, 29, S345-S348.

45. Clouse, R.E. Antidepressants for irritable bowel syndrome. Gut 2003, 52, 598-599. [CrossRef]

46. Macer, B.J.D.; Prady, S.L.; Mikocka-Walus, A. Antidepressants in Inflammatory Bowel Disease: A Systematic Review. Inflamm. Bowel Dis. 2017, 23, 534-550. [CrossRef] [PubMed]

47. Ford, A.C.; Lacy, B.E.; Harris, L.A.; Quigley, E.M.M.; Moayyedi, P. Effect of Antidepressants and Psychological Therapies in Irritable Bowel Syndrome: An Updated Systematic Review and Meta-Analysis. Am. J. Gastroenterol. 2019, 114, 21-39. [CrossRef] [PubMed]

48. Dimmock, P.W.; Wyatt, K.M.; Jones, P.W.; O’Brien, P.M.S. Efficacy of selective serotonin-reuptake inhibitors in premenstrual syndrome: A systematic review. Lancet 2000, 356, 1131-1136. [CrossRef]

49. Marjoribanks, J.; Brown, J.; O’Brien, P.M.S.; Wyatt, K. Selective serotonin reuptake inhibitors for premenstrual syndrome. Cochrane Database Syst. Rev. 2013, 6, CD001396. [CrossRef] [PubMed]

50. Lass-Flörl, C.; Dierich, M.P.; Fuchs, D.; Semenitz, E.; Jenewein, I.; Ledochowski, M. Antifungal properties of selective serotonin reuptake inhibitors against Aspergillus species in vitro. J. Antimicrob. Chemother. 2001, 48, 775-779. [CrossRef] [PubMed]

51. Méndez-Galomo, K.S.; González, G.M.; Montoya, A.M.; Becerril-García, M.A.; Solís-Villegas, E.M.; Villanueva-Lozano, H.; Robledo-Leal, E.R.; Treviño-Rangel, R.d.J. In vivo evaluation of the antifungal activity of sertraline against Aspergillus fumigatus. J. Antimicrob. Chemother. 2018, 74, 663-666. [CrossRef] 
52. Gu, W.; Guo, D.; Zhang, L.; Xu, D.; Sun, S. The synergistic effect of azoles and fluoxetine against resistant Candida albicans strains is attributed to attenuating fungal virulence. Antimicrob. Agents Chemother. 2016, 60, 6179-6188. [CrossRef] [PubMed]

53. Mandal, A.; Sinha, C.; Jena, A.K.; Ghosh, S.; Samanta, A. An investigation on in vitro and in vivo antimicrobial properties of the antidepressant: Amitriptyline hydrochloride. Braz. J. Microbiol. 2010, 41, 635-642. [CrossRef] [PubMed]

54. Andersson, J.A.; Fitts, E.C.; Kirtley, M.L.; Ponnusamy, D.; Peniche, A.G.; Dann, S.M.; Motin, V.L.; Chauhan, S.; Rosenzweig, J.A.; Sha, J.; et al. New role for FDA-approved drugs in combating antibiotic-resistant bacteria. Antimicrob. Agents Chemother. 2016, 60, 3717-3729. [CrossRef]

55. Holbrook, S.Y.L.; Garzan, A.; Dennis, E.K.; Shrestha, S.K.; Garneau-Tsodikova, S. Repurposing antipsychotic drugs into antifungal agents: Synergistic combinations of azoles and bromperidol derivatives in the treatment of various fungal infections. Eur. J. Med. Chem. 2017, 139, 12-21. [CrossRef]

56. Moraes, D.C.; Ferreira-Pereira, A. Insights on the anticandidal activity of non-antifungal drugs. J. Mycol. Med. 2019, 29, 253-259. [CrossRef]

57. Lass-Flörl, C.; Dierich, M.P.; Fuchs, D.; Semenitz, E.; Ledochowski, M. Antifungal activity against Candida species of the selective serotonin-reuptake inhibitor, sertraline. Clin. Infect. Dis. 2001, 33, 135-136. [CrossRef] [PubMed]

58. Tekintaş, Y.; Temel, A.; Ateş, A.; Eraç, B.; Metin, D.Y.; Hilmioğlu Polat, S.; Hoşgör Limoncu, M. Antifungal and antibiofilm activities of selective serotonin reuptake inhibitors alone and in combination with fluconazole. Turkish J. Pharm. Sci. 2020, 17, 667-672. [CrossRef]

59. Chen, J.; Korostyshevsky, D.; Lee, S.; Perlstein, E.O. Accumulation of an antidepressant in vesiculogenic membranes of yeast cells triggers autophagy. PLoS ONE 2012, 7, e34024. [CrossRef]

60. Zhai, B.; Wu, C.; Wang, L.; Sachs, M.S.; Lin, X. The antidepressant sertraline provides a promising therapeutic option for neurotropic cryptococcal infections. Antimicrob. Agents Chemother. 2012, 56, 3758-3766. [CrossRef]

61. Munoz-Bellido, J.L.; Munoz-Criado, S.; Garcì-Rodrìguez, J.A. Antimicrobial activity of psychotropic drugs. Selective serotonin reuptake inhibitors. Int. J. Antimicrob. Agents 2000, 14, 177-180. [CrossRef]

62. Ayaz, M.; Subhan, F.; Ahmed, J.; Khan, A.; Ullah, F.; Ullah, I.; Ali, G.; Syed, N.-H.; Hussain, S. Sertraline enhances the activity of antimicrobial agents against pathogens of clinical relevance. J. Biol. Res. 2015, 22, 1-8. [CrossRef] [PubMed]

63. Krzyżek, P.; Franiczek, R.; Krzyżanowska, B.; Łaczmański, Ł.; Migdał, P.; Gościniak, G. In vitro activity of sertraline, an antidepressant, against antibiotic-susceptible and antibiotic-resistant Helicobacter pylori strains. Pathogens 2019, 8, 228. [CrossRef]

64. Oliveira, A.S.; Gaspar, C.A.; Palmeira-de-Oliveira, R.; Martinez-de-Oliveira, J.; Palmeira-de-Oliveira, A. Anti-Candida activity of fluoxetine alone and combined with fluconazole: A synergistic action against fluconazole-resistant strains. Antimicrob. Agents Chemother. 2014, 58, 4224-4226. [CrossRef] [PubMed]

65. Karine de Sousa, A.; Rocha, J.E.; Gonçalves de Souza, T.; Sampaio de Freitas, T.; Ribeiro-Filho, J.; Melo Coutinho, H.D. New roles of fluoxetine in pharmacology: Antibacterial effect and modulation of antibiotic activity. Microb. Pathog. 2018, 123, 368-371. [CrossRef]

66. Zuo, J.; Quinn, K.K.; Kye, S.; Cooper, P.; Damoiseaux, R.; Krogstad, P. Fluoxetine is a potent inhibitor of coxsackievirus replication. Antimicrob. Agents Chemother. 2012, 56, 4838-4844. [CrossRef]

67. Foletto, V.S.; Serafin, M.B.; Bottega, A.; da Rosa, T.F.; de S. Machado, C.; Coelho, S.S.; Hörner, R. Repositioning of fluoxetine and paroxetine: Study of potential antibacterial activity and its combination with ciprofloxacin. Med. Chem. Res. 2020, 29, 556-563. [CrossRef]

68. Costa Silva, R.A.; da Silva, C.R.; de Andrade Neto, J.B.; da Silva, A.R.; Campos, R.S.; Sampaio, L.S.; do Nascimento, F.B.S.A.; da Silva Gaspar, B.; da Cruz Fonseca, S.G.; Josino, M.A.A.; et al. In vitro anti-Candida activity of selective serotonin reuptake inhibitors against fluconazole-resistant strains and their activity against biofilm-forming isolates. Microb. Pathog. 2017, 107, 341-348. [CrossRef] [PubMed]

69. Nobile, C.J.; Ennis, C.L.; Hartooni, N.; Johnson, A.D.; Lohse, M.B. A selective serotonin reuptake inhibitor, a proton pump inhibitor, and two calcium channel blockers inhibit candida albicans biofilms. Microorganisms 2020, 8, 756. [CrossRef]

70. Holmes, A.R.; Keniya, M.V.; Ivnitski-Steele, I.; Monk, B.C.; Lamping, E.; Sklar, L.A.; Cannon, R.D. The monoamine oxidase A inhibitor clorgyline is a broad-spectrum inhibitor of fungal ABC and MFS transporter efflux pump activities which reverses the azole resistance of Candida albicans and Candida glabrata clinical isolates. Antimicrob. Agents Chemother. 2012, 56, 1508-1515. [CrossRef] [PubMed]

71. Burin, R.; Shah, D.H. Phenelzine and Amoxapine Inhibit Tyramine and d-Glucuronic Acid Catabolism in Clinically Significant Salmonella in A Serotype-Independent Manner. Pathogens 2021, 10, 469. [CrossRef]

72. Caldara, M.; Marmiroli, N. Tricyclic antidepressants inhibit Candida albicans growth and biofilm formation. Int. J. Antimicrob. Agents 2018, 52, 500-505. [CrossRef]

73. Caldara, M.; Marmiroli, N. Known antimicrobials versus nortriptyline in Candida albicans: Repositioning an old drug for new targets. Microorganisms 2020, 8, 742. [CrossRef]

74. Rajasekharan, S.K.; Lee, J.H.; Lee, J. Aripiprazole repurposed as an inhibitor of biofilm formation and sterol biosynthesis in multidrug-resistant Candida albicans. Int. J. Antimicrob. Agents 2019, 54, 518-523. [CrossRef]

75. Ramón-García, S.; Ng, C.; Anderson, H.; Chao, J.D.; Zheng, X.; Pfeifer, T.; Av-Gay, Y.; Roberge, M.; Thompson, C.J. Synergistic drug combinations for tuberculosis therapy identified by a novel high-throughput screen. Antimicrob. Agents Chemother. 2011, 55, 3861-3869. [CrossRef] 
76. Kathwate, G.H.; Shinde, R.B.; Karuppayil, S.M. Antiepileptic drugs inhibit growth, dimorphism, and biofilm mode of growth in human pathogen Candida albicans. Assay Drug Dev. Technol. 2015, 13, 307-312. [CrossRef] [PubMed]

77. Ayoglu, H.; Kulah, C.; Turan, I. Antimicrobial effects of two anaesthetic agents: Dexmedetomidine and midazolam. Anaesth. Intensive Care 2008, 36, 681-684. [CrossRef] [PubMed]

78. Keleş, G.T.; Kurutepe, S.; Tok, D.; Gazi, H.; Dinç, G. Comparison of antimicrobial effects of dexmedetomidine and etomidate-lipuro with those of propofol and midazolam. Eur. J. Anaesthesiol. 2006, 23, 1037-1040. [CrossRef] [PubMed]

79. Kennedy, M.J.; Volz, P.A. Ecology of Candida albicans gut colonization: Inhibition of Candida adhesion, colonization, and dissemination from the gastrointestinal tract by bacterial antagonism. Infect. Immun. 1985, 49, 654-663. [CrossRef]

80. Kumamoto, C.A. Candida biofilms. Curr. Opin. Microbiol. 2002, 5, 608-611. [CrossRef]

81. Kumamoto, C.A. Inflammation and gastrointestinal Candida colonization. Curr. Opin. Microbiol. 2011, 14, 386-391. [CrossRef] [PubMed]

82. Weig, M.; Gross, U.; Muhlschlegel, F. Clinical aspects and pathogenesis of Candida infection. Trends Microbiol. 1998, 6, 468-470. [CrossRef]

83. Chandra, J.; Kuhn, D.M.; Mukherjee, P.K.; Hoyer, L.L.; McCormick, T.; Ghannoum, M.A. Biofilm formation by the fungal pathogen Candida albicans: Development, architecture, and drug resistance. J. Bacteriol. 2001, 183, 5385-5394. [CrossRef] [PubMed]

84. Ramage, G.; Mowat, E.; Jones, B.; Williams, C.; Lopez-Ribot, J. Our Current Understanding of Fungal Biofilms. Crit. Rev. Microbiol. 2009, 35, 340-355. [CrossRef] [PubMed]

85. Wenzel, R.P. Nosocomial Candidemia: Risk Factors and Attributable Mortality. Clin. Infect. Dis. 1995, 20, 1531-1534. [CrossRef]

86. Lepak, A.; Andes, D. Fungal Sepsis: Optimizing Antifungal Therapy in the Critical Care Setting. Crit. Care Clin. 2011, 27, 123-147. [CrossRef]

87. Anderson, J.B. Evolution of antifungal-drug resistance: Mechanisms and pathogen fitness. Nat. Rev. Microbiol. 2005, 3, 547-556. [CrossRef] [PubMed]

88. Bonhomme, J.; d'Enfert, C. Candida albicans biofilms: Building a heterogeneous, drug-tolerant environment. Curr. Opin. Microbiol. 2013, 16, 398-403. [CrossRef] [PubMed]

89. Mba, I.E.; Nweze, E.I. Mechanism of Candida pathogenesis: Revisiting the vital drivers. Eur. J. Clin. Microbiol. Infect. Dis. 2020, 39, 1797-1819. [CrossRef]

90. Naglik, J.R.; Challacombe, S.J.; Hube, B. Candida albicans Secreted Aspartyl Proteinases in Virulence and Pathogenesis. Microbiol. Mol. Biol. Rev. 2003, 67, 400-428. [CrossRef]

91. Mollinedo, F. Lipid raft involvement in yeast cell growth and death. Front. Oncol. 2012, 2, 140. [CrossRef]

92. Yu, Q.; Jia, C.; Dong, Y.; Zhang, B.; Xiao, C.; Chen, Y.; Wang, Y.; Li, X.; Wang, L.; Zhang, B.; et al. Candida albicans autophagy, no longer a bystander: Its role in tolerance to ER stress-related antifungal drugs. Fungal Genet. Biol. 2015, 81, 238-249. [CrossRef] [PubMed]

93. Scorzoni, L.; Sangalli-Leite, F.; de Lacorte Singulani, J.; de Paula e Silva, A.C.A.; Costa-Orlandi, C.B.; Fusco-Almeida, A.M.; Mendes-Giannini, M.J.S. Searching new antifungals: The use of in vitro and in vivo methods for evaluation of natural compounds. J. Microbiol. Methods 2016, 123, 68-78. [CrossRef] [PubMed]

94. Rhein, J.; Morawski, B.M.; Hullsiek, K.H.; Nabeta, H.W.; Kiggundu, R.; Tugume, L.; Musubire, A.; Akampurira, A.; Smith, K.D.; Alhadab, A.; et al. Efficacy of adjunctive sertraline for the treatment of HIV-associated cryptococcal meningitis: An open-label dose-ranging study. Lancet Infect. Dis. 2016, 16, 809-818. [CrossRef]

95. Villanueva-Lozano, H.; Treviño-Rangel, R.d.J.; González, G.M.; Hernández-Rodríguez, P.A.; Camacho-Ortiz, A.; Castillo-Reyna, L.; Galindo-Alvarado, S.G.; Martínez-Reséndez, M.F. Clinical evaluation of the antifungal effect of sertraline in the treatment of cryptococcal meningitis in HIV patients: A single Mexican center experience. Infection 2018, 46, 25-30. [CrossRef]

96. Verma, N.A.; Zheng, X.T.; Harris, M.U.; Cadichon, S.B.; Malm-Aldana, H.; Khetsuriani, N.; Oberste, M.S.; Shulman, S.T. Outbreak of life-threatening coxsackievirus B1 myocarditis in neonates. Clin. Infect. Dis. 2009, 49, 759-763. [CrossRef]

97. Wilson, T.J.; Blackledge, M.S.; Vigueira, P.A. Resensitization of methicillin-resistant Staphylococcus aureus by amoxapine, an FDA-approved antidepressant. Heliyon 2018, 4, e00501. [CrossRef]

98. Gillard, K.; Miller, H.B.; Blackledge, M.S. Tricyclic amine antidepressants suppress $\beta$-lactam resistance in methicillin-resistant Staphylococcus aureus (MRSA) by repressing mRNA levels of key resistance genes. Chem. Biol. Drug Des. 2018, 92, 1822-1829. [CrossRef]

99. Bonde, M.; Højland, D.H.; Kolmos, H.J.; Kallipolitis, B.H.; Klitgaard, J.K. Thioridazine affects transcription of genes involved in cell wall biosynthesis in methicillin-resistant Staphylococcus aureus. FEMS Microbiol. Lett. 2011, 318, 168-176. [CrossRef] [PubMed]

100. Prasad, R.; Gaur, N.; Gaur, M.; Komath, S. Efflux Pumps in Drug Resistance of Candida. Infect. Disord.-Drug Targets 2008, 6, 69-83. [CrossRef] [PubMed]

101. Pan, Y.P.; Xu, Y.H.; Wang, Z.X.; Fang, Y.P.; Shen, J.L. Overexpression of MexAB-OprM efflux pump in carbapenem-resistant Pseudomonas aeruginosa. Arch. Microbiol. 2016, 198, 565-571. [CrossRef]

102. Nikaido, H.; Basina, M.; Nguyen, V.; Rosenberg, E.Y. Multidrug efflux pump AcrAB of Salmonella typhimurium excretes only those $\beta$-lactam antibiotics containing lipophilic side chains. J. Bacteriol. 1998, 180, 4686-4692. [CrossRef] [PubMed] 
103. Marmiroli, N.; Tedeschi, F.; Sabatini, M.A.; Truzzi, G.; Ferrari, C.; Puglisi, P.P. Relationship between growth inhibition and mitochondrial function in petite-negative yeasts. II. Effects of central nervous system drugs upon pathogenic and non-pathogenic Candida species. Biol. Cell 1985, 53, 75-79. [CrossRef]

104. Uesono, Y.; Araki, T.; Toh-e, A. Local Anesthetics, Antipsychotic Phenothiazines, and Cationic Surfactants Shut Down Intracellular Reactions through Membrane Perturbation in Yeast. Biosci. Biotechnol. Biochem. 2008, 72, 2884-2894. [CrossRef] [PubMed]

105. Uesono, Y.; Toh-e, A.; Kikuchi, Y.; Terashima, I. Structural analysis of compounds with actions similar to local anesthetics and antipsychotic phenothiazines in yeast. Yeast 2011, 28, 391-404. [CrossRef] [PubMed]

106. Caldara, M.; Graziano, S.; Gulli, M.; Cadonici, S.; Marmiroli, N. Off-target effects of neuroleptics and antidepressants on saccharomyces cerevisiae. Toxicol. Sci. 2017, 156, 538-548. [CrossRef] [PubMed]

107. Ericson, E.; Gebbia, M.; Heisler, L.E.; Wildenhain, J.; Tyers, M.; Giaever, G.; Nislow, C. Off-target effects of psychoactive drugs revealed by genome-wide assays in yeast. PLoS Genet. 2008, 4, e1000151. [CrossRef]

108. Lang, X.; Luan, X.; Gao, C.; Jiang, Y. Recent progress of acridine derivatives with antitumor activity. Prog. Chem. 2012, 24, 1497-1505.

109. Ait Chait, Y.; Mottawea, W.; Tompkins, T.A.; Hammami, R. Unravelling the antimicrobial action of antidepressants on gut commensal microbes. Sci. Rep. 2020, 10, 1-11. [CrossRef] [PubMed]

110. O'Mahony, S.M.; Clarke, G.; Borre, Y.E.; Dinan, T.G.; Cryan, J.F. Serotonin, tryptophan metabolism and the brain-gut-microbiome axis. Behav. Brain Res. 2015, 277, 32-48. [CrossRef]

111. Kwon, Y.H.; Wang, H.; Denou, E.; Ghia, J.E.; Rossi, L.; Fontes, M.E.; Bernier, S.P.; Shajib, M.S.; Banskota, S.; Collins, S.M.; et al. Modulation of Gut Microbiota Composition by Serotonin Signaling Influences Intestinal Immune Response and Susceptibility to Colitis. CMGH 2019, 7, 709-728. [CrossRef]

112. Özoğul, F. Production of biogenic amines by Morganella morganii, Klebsíella pneumoniae and Hafnia alvei using a rapid HPLC method. Eur. Food Res. Technol. 2004, 219, 465-469. [CrossRef]

113. Shishov, V.A.; Kirovskaya, T.A.; Kudrin, V.S.; Oleskin, A.V. Amine neuromediators, their precursors, and oxidation products in the culture of Escherichia coli k-12. Appl. Biochem. Microbiol. 2009, 45, 494-497. [CrossRef]

114. Kelly, J.R.; Borre, Y.; O’ Brien, C.; Patterson, E.; El Aidy, S.; Deane, J.; Kennedy, P.J.; Beers, S.; Scott, K.; Moloney, G.; et al. Transferring the blues: Depression-associated gut microbiota induces neurobehavioural changes in the rat. J. Psychiatr. Res. 2016, 82, 109-118. [CrossRef] [PubMed]

115. Lin, P.; Ding, B.; Feng, C.; Yin, S.; Zhang, T.; Qi, X.; Lv, H.; Guo, X.; Dong, K.; Zhu, Y.; et al. Prevotella and Klebsiella proportions in fecal microbial communities are potential characteristic parameters for patients with major depressive disorder. J. Affect. Disord. 2017, 207, 300-304. [CrossRef]

116. Inserra, A.; Rogers, G.B.; Licinio, J.; Wong, M.L. The Microbiota-Inflammasome Hypothesis of Major Depression. BioEssays 2018, 40, 1800027. [CrossRef]

117. Nikolova, V.L.; Cleare, A.J.; Young, A.H.; Stone, J.M. Updated Review and Meta-Analysis of Probiotics for the Treatment of Clinical Depression: Adjunctive vs. Stand-Alone Treatment. J. Clin. Med. 2021, 10, 647. [CrossRef]

118. Okubo, R.; Koga, M.; Katsumata, N.; Odamaki, T.; Matsuyama, S.; Oka, M.; Narita, H.; Hashimoto, N.; Kusumi, I.; Xiao, J.; et al. Effect of bifidobacterium breve A-1 on anxiety and depressive symptoms in schizophrenia: A proof-of-concept study. J. Affect. Disord. 2019, 245, 377-385. [CrossRef]

119. Akkasheh, G.; Kashani-Poor, Z.; Tajabadi-Ebrahimi, M.; Jafari, P.; Akbari, H.; Taghizadeh, M.; Memarzadeh, M.R.; Asemi, Z.; Esmaillzadeh, A. Clinical and metabolic response to probiotic administration in patients with major depressive disorder: A randomized, double-blind, placebo-controlled trial. Nutrition 2016, 32, 315-320. [CrossRef] [PubMed]

120. Osadchiy, V.; Martin, C.R.; Mayer, E.A. The Gut-Brain Axis and the Microbiome: Mechanisms and Clinical Implications. Clin. Gastroenterol. Hepatol. 2019, 17, 322-332. [CrossRef] 